\title{
A MODEL FOR INTRODUCING STRATEGIES IN SUSTAINABLE DEVELOPMENT OF SMALL-SCALE ENTERPRISES IN SERBIA
}

\author{
UDC: $334.713: 502.131 .1(497.11)$ \\ Original Scientific Paper \\ Miloš VORKAPIĆ ${ }^{1}$, Bogdan POPOVIĆ ${ }^{2}$, Dragan ĆOĆKALO ${ }^{3}$, Dejan ĐORĐEVIĆ ${ }^{3}$, \\ Siniša G. MINIĆ ${ }^{4}$ \\ ${ }^{1}$ University of Belgrade, Institute of Chemistry, Technology and Metallurgy - Centre for Microelectronic \\ Technology and Monocrystals, 11000 Belgrade, Njegoševa 12, Republic of Serbia \\ E-mail: worcky@nanosys.ihtm.bg.ac.rs \\ ${ }^{2}$ University of Belgrade, Institute of Chemistry, Technology and Metallurgy - Centre for Microelectronic \\ Technology and Monocrystals, 11000 Belgrade, Njegoševa 12, Republic of Serbia \\ ${ }^{3}$ University of Novi Sad, Technical faculty "Mihajlo Pupin" Zrenjanin, 23000 Zrenjanin, Đure Đakovića bb, \\ Republic of Serbia \\ ${ }^{4}$ University of Priština, Teachers' Training Faculty, 38218 Leposavić, Nemanjina bb, Republic of Serbia \\ Paper received: 04.11.2015.; Paper accepted: 21.11.2015.

\begin{abstract}
This paper presents the algorithm for introducing the strategies ensuring the sustainable development of enterprises, but also provides improvement of small-scale manufacturing process. Three strategies are given in the algorithm: Remanufacturing, modification and 4R. Credibility of the algorithm is reflected in: defining the basic input and output elements, defining the important environmental factors, importance of resources and in defining a sustainable production process. The combination of the aforementioned strategies enables local enterprises to perceive easily the importance of achievements in developed countries. Reuse of products is implemented through: verification, disassembling, replacement of parts, installation of modified parts and components, cleaning, re-assembling and testing. The algorithm gives an example of how to save materials and energy appearing as huge losses in manufacturing process.
\end{abstract}

Keywords: algorithm, modification, remanufacturing, 4R, small-scale enterprises.

\section{INTRODUCTION}

The subject of this paper is to analyze small-scale production and the possibility of sustainable development of enterprises. The small-scale production means that production is done according to the customer's order. The small-scale production is primarily focused on the customer and turned to customer's requests and wishes.

Customers must submit detailed specifications, so a manufacturer can design and make a product that will meet their needs (Schmitz, 2004). The same process applies for the changes of the existing products if the modification of parts or components is being done, but the changes on the new product should not be neglected. Many manufacturers prefer that consumers determine the required functionality arising from the product, as well as other critical ecological attributes (size, electrical constraints and vibrations).

Many authors, (Rosenblatt \& Lee, 1986; Anderson 1987; Mallidi 1999; Morroni 2009) define three basic types of inputs: materials, energy and other factors (water, tools, supplies, information). The most common output values in the process of transformation are: the final product, material losses, loss of energy, wasted time and water losses.

\section{PRODUCT LIFE CYCLE}

Rapidly changing of technology makes the existing products being obsolete. Product life cycle (PLC) is getting shorter, or just a quick and successful product development is primary for survival of the company. The concept of product life cycle (PLC) enables consideration of all factors affecting the 
market, sales volume and profit. The following stages of the product life cycle are described in literature (Jović, 1997): introduction, growth, maturity, decreasing and mortality.

For further analysis it is both important and interesting to examine product's maturity stage. On the basis of this stage, a company can examine the strategies that will be applied in order to provide sustainable development of production. In the maturity stage, the sales volume is at high level, first the rise is recorded and then it is gradually stabilized during the early part of this stage, before it starts falling. Duration of this phase should be extended by taking marketing action. This is the stage in which a large number of enterprises offer various products to the customers, due to a strong competition, but customers do not buy any more product from a specific company. At this stage, development of a new product should be planned in order to provide survival and better competitiveness on the market. Serious enterprises do not wait for the phase of stagnation (or decadence) of their products to start modification (Crawford \& Benedetto, 2000).

\section{Modified or a new product}

Modern enterprises are facing with ever shorter PLC with the increasing complexity of products. Today, the concept of PLC includes: quicker product development through the supply of components for manufacturing, assembly and service; disassembly, repairing and reusing of parts and components and avoiding the use of toxic substances (Jeffrey and Hunt, 1985; Ali et al., 1995; Griffin, 1997; Westkàmper et al. 1999).

In new products realization, more attention is paid to pure products. There is a change of the production process during the PLC, with the aim of reducing waste and emissions. Projects of cleaner production lead to savings in companies. On the other hand, they motivate managers and employees to move in that direction (Achanga, 2006).

Product modification involves a change of one or more components. With the product modification, the company changed product characteristics, such as: the quality and properties. Thus, modification can be seen as a corporate strategy whose aim is to increase functionality and quality of products. The critical point for modification occurs in the phase of stagnation of products on the market.
Although the new products provide greater opportunities and better results on the market, the emphasis is still placed on modified products. In this way, enterprises tend to avoid large investments in product development as well as the uncertainty of its success on the market.

\section{Flowchart}

Diagram of material flow is given in manufacturing process, in the Figure 1 (Maxwell \& Van der Vorst, 2003; Sladić, 2008). The focus is on sustainable manufacturing in the field of sound and sustainable development of small and mediumsized enterprises with a special emphasis on environmental protection (Schmitz, 1995; Frijns \& Van Vliet, 1999; Desai, 2008). Flowchart, in small-scale enterprises, implies active participation of management, from reducing costs of input values, up to monitoring, measuring and control of input, intermediate and output elements. The manufacturing process consists of three subprocesses: production preparation (preparatory stages), production process and ending of production process.

Managing of production elements is done through quality control, which in itself includes (Sladić, 2008): 1) analysis, measurement and correction of output parameters and 2) improvement of input parameters (see figure 1). In this regard, in the manufacturing process and sustainable development, the attention should be paid to organization of the manufacturing process through (Haushilda et al., 2004): reducing consumption of energy and resources, reducing the use of toxic materials; using material of good-quality and characteristics, possibility of upgrading, repairs and recycling of products.

First, material is being bought from suppliers, then input control of material comes and finally semifinished products are stored in the warehouse. The following phase is a manufacturing process. The output control of a new product is taking place, and realized/new product is being stored in a warehouse of finished products, after controlling.

According to such described condition, material is being lost permanently. Communication in a sellerbuyer relationship has been reduced to pure/true sale, so the producer does not have feedback about what is going on with the product during exploitation or what is going on with the product at the end of its life cycle (PLC). 


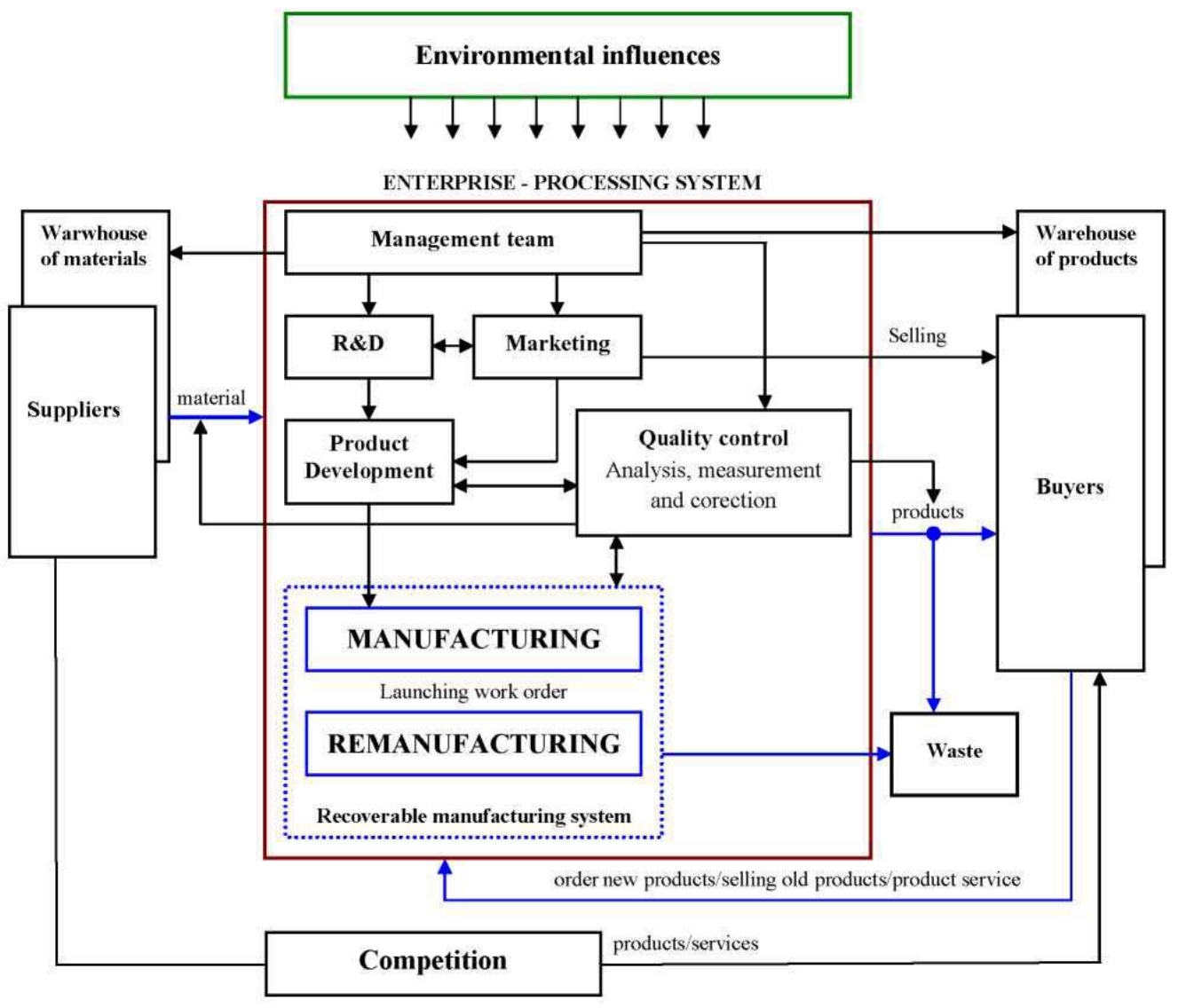

Figure: Flow chart of material in processing/manufacturing process

Three important strategies are implemented in the Flow chart, in order to establish and maintain a renewable production system: remanufacturing, $4 \mathrm{R}$ and modification. The Flow chart of material in manufacturing process represents the backbone of the efficient business enterprises with emphasis on environmental protection (Ward et al., 1996). The customers' feedback has been provided, namely customers appear as suppliers of used goods or raw materials for reprocessing (Östlin et al., 2008). This Flow chart provides: reduction of waste, recycling of old parts and reuse of products at the end of life (PLC).

\section{REMANUFACTURING AND MODIFICATION}

The production system is complete if it contains elements of production and remanufacture. A system can be considered satisfactory if there is a demand for manufacturing and remanufacturing (see figure 1) (Konstantaras \& Skouri, 2010). This system includes the purchase of products from customers, then storing them and later use in the process of remanufacturing.

Remanufacturing is defined as a process of renewing end-of-life products (Mangun \&
Thurston, 2002), ie. It becomes an economic and environmentally superior alternative production (Zhon et al, 2014). It involves dismantling, cleaning, measuring and testing of parts. Finally, the usable parts are put into storage (Kerr \& Rian, 2001).This means that the product can be made up of old and new components.

The example of an application of remanufacturing (or reuse of products) can be found in the study of (Kivanc \& Gupta, 2000) - the authors indicated that it can be saved up to $85 \%$ of the weight of a product, so it is necessary $80 \%$ less energy for realization of the product.

Remanufacturing enables making additional value to the company as it comes to the savings in material, energy and the engagement of the labor force (Lee et al., 2010). Many companies have become successful by applying production, because the products generate more profit, according to (Zhon et al, 2014). Gehin et al. (Gehin et al 2008), the following advantages of remanufacturing are present: 1) companies that use recycled products, reduce its expenses (reducing the products price and price of disposal), 2) application of remanufacturing itself in the marketing sense is a strategy for increasing profits, 3) specialized equipment are used in the 
production process (it comes to the product improvement, reducing disposal costs), 4) optimizing tools for assembly and disassembly, 5) remanufacturing provides stability in investments and business enterprises (increasing market control and new jobs, expertise of designers) and 6) there is a dependency of suppliers.

On the other hand, the increasing percentage of the used products and maintenance of quality remanufacturing process are getting more complicated and expensive. Östlin et al. (Östlin et al. 2008) indicate that the companies also have problems with the supply chain since they have to collect the used products from customers, which requires certain time, and the quality of the used products is mostly unknown.

Therefore, it is necessary that vital elements of the product are of a modular design (Seliger, 2007). The basic idea of modular design is to put parts or modules (or connect) in different products (Sanchez \& Mahoney, 1996), but also to eliminate the non-conformities during the reuse of the product (Kambhampati \& Hendler, 1992). Customers, in this case, get an impression that there is a large number of different products. Zhang and Gershenson (Zhang \& Gershenson 2002) point out that the modular design is a key element in the sustainable development of an enterprise or in the case when the product is between the mature stage and declining and end of life stage. Unfortunately, design is often marginalized in MSP (Achanga et al., 2006).

\section{THE 4R STRATEGY}

This strategy includes in itself (Achanga et al., 2006): 1.) reducing material waste to a minimum (Reduction); 2.) reuse of waste materials (Reuse); 3.) collecting material waste in order to preserve the environment (Recycling), 4.) regeneration of raw materials and energy from waste materials that cannot be reduced, reused or recycled (Recovery), (Ayres, 2003).

Product design plays an important role in quick and easy disassembling of components. During this phase significant design decisions can be made on the further implementation of products reflected in technical and economic feasibility, functionality and structural compactness of products, overall functionality and structural compactness of products (Desai \& Mital, 2003). In this regard, $(\mathrm{Gu}$ \& Sosale 1999), these authors developed a methodology that helped in deploying modular design through the analysis of 4R strategy .

\section{ALGORITHM FOR INTRODUCTION OF STRATEGIES}

For small-scale production enterprises there are mainly open supply chains which take place at the entrance of raw materials and at the output of the final product. However, it is different in practice because losses can appear at the output of the finished product which can have the form of machine failure, poorly made pieces of broken tools due to improper handling, increase in nonproductive time of employees, etc...

In the open supply chains, buyers and sellers act as independent entities. Therefore, enterprises have large inventories of raw materials and provide additional capacity for defense from market changes (Chopra \& Meindl, 2001). However, this approach represents a major risk for sustainable development of small-scale production enterprises.

The algorithm provides a feedback loop between sellers and customers. Customer first appears as a supplier, or appears in the role of a seller of used products. In this way, the customer helps the company to reduce the accumulation of raw materials and losses in the realization of new products.

The starting raw material in the algorithm is the reuse of old products or parts of products (see figure 2). So it is possible to reuse some parts without any previous renovation and finishing. In order to implement these procedures it is very important to design a product suitable to this type of maintenance such as: accessibility and interchangeability of parts (modularity), dismantling circuits, possibility of finishing /processing (Boothroyd et al., 1994).

At the beginning, the product is controlled regardless of whether it is used (in use) or out of use (technologically outdated). The first issue is arising: Is the product correct or not? (1). If the product is correct (in function) the customer decides on product lifecycle (PLC) through the following decisions:

A1: Is it going to modify the existing product?

A2: Is it going to replace the existing product with a new product? or

A3: Is it going to use the product until its extinction? 
If the product is not good (in operation) the second question arises: Is the product in warranty period?(2). For a product which is in warranty period, servicing must be provided. However, a customer can decide to sell the product, despite the aforementioned conditions, but he can also regulate the special contract for purchasing products. The process of servicing includes disassembly of products, analysis of regularities or irregularities of disassembled components.

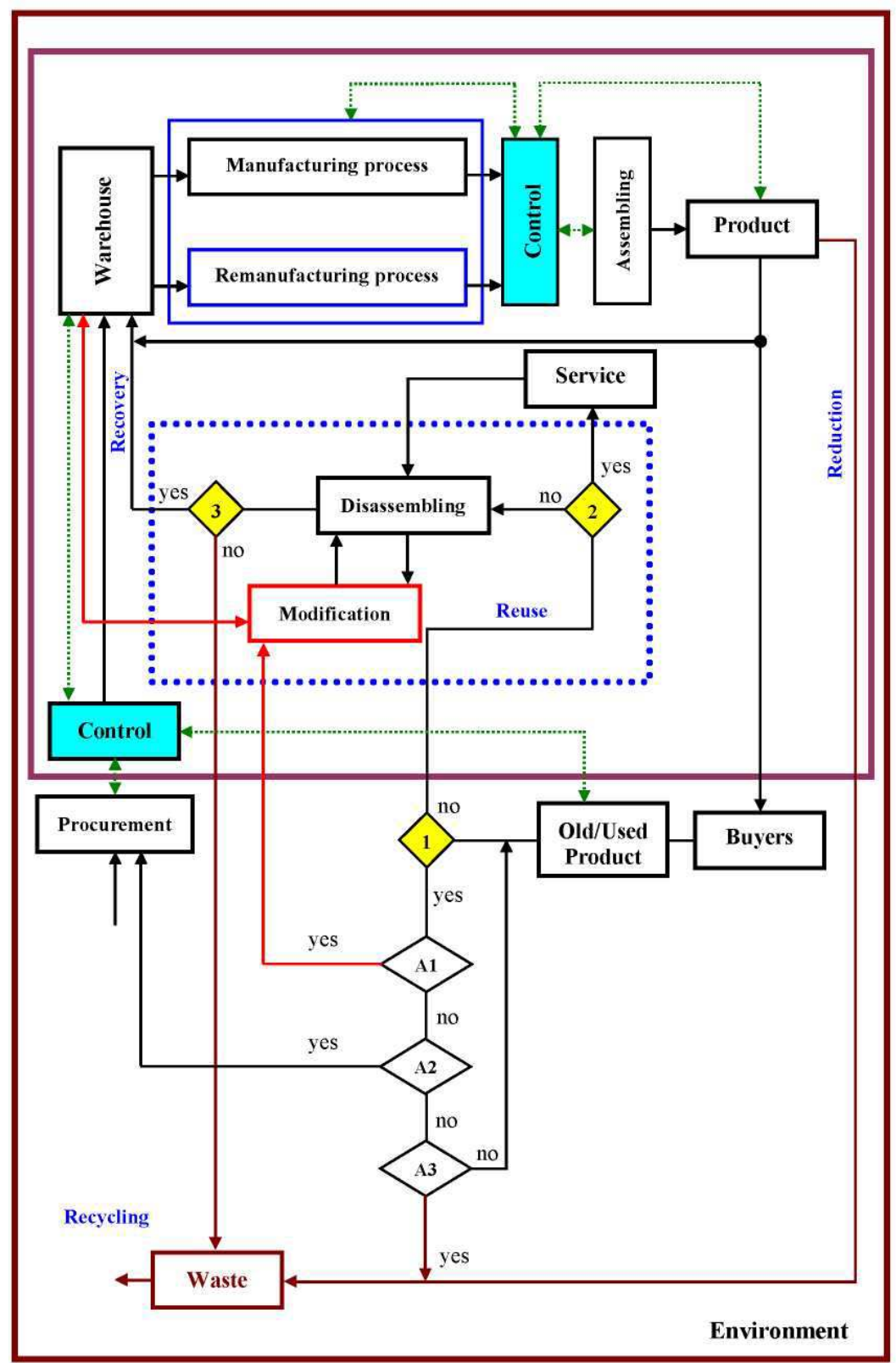

Figure 2: The algorithm with implemented strategies

In this regard, the third issue arises: Are disassembled components in use? (3). If they are not, the defective elements are depositing in waste (they become irrecoverable elements). If the elements are correct, then they should be cleaned and stored in a warehouse. The correct pieces are repaired and refreshed during the process of remanufacturing and thus become elements for reuse in the process of realization of the new product. Correct elements can be changed and modified by parts and components, ie. The algorithm allows correcting mistakes, observed by manufacturers during this phase. Modified components are refreshed realization of new products, and can be found in a combination with remanufactured components or dismantled ones with other structures or circuits.

Correct elements or modified elements are taken from the warehouse semi-products (new, modified or repaired elements / circuits). In this case, a work order to service the product has to be made. After 
the manufacturing process, it is necessary to perform the output control of the production processes and products.

For a product that is not within the warranty period product dismantling is carried out; the procedure as in the third question is applied for this step (see figure 2).

In the algorithm, waste is not considered as a permanently lost resource, product or material. In this case the waste represents a resource that should be given more attention especially in the field of industry in Serbia. Furthermore, a product modification reduces losses, not only in the material, but also in design and the engagement of capacity. The algorithm provides assistance and designers to make decisions regarding the design of environmentally friendly products, as environmental considerations are increasingly involved in the product development process (Akermark, 1999).

\section{CONCLUSION}

The paper gives an example of how small businesses on the territory of the Republic of Serbia can save materials and energy. This paper tends to explain the significance of the introduction of three strategies for sustainable development of enterprises, through: modification of product remanufacturing and 4R. Implementation of afore mentioned strategies in the field of reparations, replacement parts and assemblies and installation of modified components should reduce consumption of materials and energy.

The set algorithm represents a procedure for domestic enterprises in order to improve the production process and secure communications with customers. The algorithm is based on the existence of waste which is considered as an important resource. Unfortunately, in domestic companies there is a strategic decision on the reuse of waste as a resource.

The customer also appears in the role of a supplier of used / second hand items during a transformative process of getting feedback. In this way, the algorithm enables new business philosophy of "more life cycles" by introducing a product design.

By detailed analysis and application of the algorithm, small businesses on the territory of the Republic of Serbia will be able to produce new, repaired or modified products with as little loss of energy and materials as possible and with less creation of waste harmful to the environment, to better analyze the life cycle of the product and implement environmental protection as a new (additional) strategic decision in the sustainable development of enterprises.

Further studies should focus on quality control. The algorithm opens the possibility for applying the standardized management systems such as ISO 9001 and ISO 14001 or integrating them into a single management system. Series of ISO 9001 deals only with one segment of quality system management, while ISO 14001 deals with environmental management including the protection, restoration and improvement of the environment build on standards ISO 9001.

It would also be very interesting to analyze and include the waste, which physically exists in domestic enterprises, into the research but there is little literary sources and results from this field in Serbia. The algorithm would spread and gain importance in this way because waste management is considerably significant in developed industries of the world.

\section{REFERENCES}

Achanga, P., Shehab, E., Roy, R., \& Nelder, G. (2006). Critical success factors for lean implementation within SMEs. Journal of Manufacturing Technology Management, 17(4), 460-471.

Akermark, A. M. (1999, February). Design for environment from the designers perspective. Paper presented at the Environmentally Conscious Design and Inverse Manufacturing, 1999. Proceedings. EcoDesign'99: First International Symposium On

Ali, A., Krapfel, R., \& LaBahn, D. (1995). Product innovativeness and entry strategy: impact on cycle time and break-even time. Journal of product innovation management, 12(1), 54-69.

Anderson, C. L. (1987). The production process: Inputs and wastes. Journal of Environmental Economics and Management, 14(1), 1-12.

Ayres, R. U. (1997). Metals recycling: economic and environmental implications. Resources, conservation and recycling, 21(3), 145-173.

Boothroyd, G. (1994). Product design for manufacture and assembly. Computer-Aided Design, 26(7), 505520.

Chopra, S., \& Meindl, P. (2007). Supply chain management. Strategy, planning \& operation (pp. 265-275). Gabler.

Crawford, C. M., \& Benedetto C. A. D. (2000). New Products Management (Sixth ed.). New York: McGraw - Hill. 
Desai, D. A. (2008). Cost of quality in small-and medium-sized enterprises: case of an Indian engineering company. Production planning and control, 19(1), 25-34.

Frijns, J., \& Van Vliet, B. (1999). Small-scale industry and cleaner production strategies. World Development, 27(6), 967-983.

Gehin, A., Zwolinski, P., \& Brissaud, D. (2008). A tool to implement sustainable end-of-life strategies in the product development phase. Journal of Cleaner Production, 16(5), 566-576.

Griffin, A. (1997). Modeling and measuring product development cycle time across industries. Journal of engineering and technology management, 14(1), 124.

Gu, P., \& Sosale, S. (1999). Product modularization for life cycle engineering. Robotics and ComputerIntegrated Manufacturing, 15(5), 387-401.

Hauschild, M. Z., Jeswiet, J., \& Alting, L. (2004). Design for environment-do we get the focus right?. CIRP Annals-Manufacturing Technology, 53(1), 1-4.

Jeffrey, K. R., \& Hunt, D. (1985). Design in small manufacturing companies in Scotland. Design Studies, 6(1), 18-24.

Jović, M. ( 1997). Međunarodni marketing-od izvoznog ka globalnom konceptu. Beograd: Međunarodna marketing agencija, Institut ekonomskih nauka.

Kambhampati, S., \& Hendler, J. A. (1992). A validation-structure-based theory of plan modification and reuse. Artificial Intelligence, 55(2), 193-258.

Kerr, W., \& Ryan, C. (2001). Eco-efficiency gains from remanufacturing: A case study of photocopier remanufacturing at Fuji Xerox Australia. Journal of cleaner production, 9(1), 75-81.

Kivanc, H., \& Gupta, M. S. (2000)). Effect of Reusable Rate Variation on the Performance Remanufacturing Systems, Paper presented at the Environmentally Conscions Manufacturing Conference, Boston, Massachusetts, USA.

Konstantaras, I., \& Skouri, K. (2010). Lot sizing for a single product recovery system with variable setup numbers. European Journal of Operational Research, 203(2), 326-335.

Lee, H. B., Cho, N. W., \& Hong, Y. S. (2010). A hierarchical end-of-life decision model for determining the economic levels of remanufacturing and disassembly under environmental regulations. Journal of Cleaner Production, 18(13), 1276-1283.

Mallidi, K., Paraskevopoulos, A. T., \& Paganelli, P. (1999). Process modelling in small-medium enterprise networks. Computers in industry, 38(2), $149-158$

Mangun, D., \& Thurston, D. L. (2002). Incorporating component reuse, remanufacture, and recycle into product portfolio design. Engineering Management, IEEE Transactions on, 49(4), 479-490.

Maxwell, D., \& Van der Vorst, R. (2003). Developing sustainable products and services. Journal of Cleaner Production, 11(8), 883-895.

Morroni, M. (2009). Production process and technical change: Cambridge university press.

Östlin, J., Sundin, E., \& Björkman, M. (2008). Importance of closed-loop supply chain relationships for product remanufacturing. International Journal of Production Economics, 115(2), 336-348.

Rosenblatt, M. J., \& Lee, H. L. (1986). Economic production cycles with imperfect production processes. IIE transactions, 18(1), 48-55.

Sanchez, R., J. T. Mahoney. (1996). Modularity, flexibility, and knowledge management in product and organization design. Strategic Management Journal, 17(S2), 63-76.

Schmitz, H. (1995). Collective efficiency: Growth path for small $\square$ scale industry. The journal of development studies, 31(4), 529-566.

Schmitz, H. (2004). Local enterprises in the global economy: Issues of governance and upgrading. Edward Elgar Publishing.

Seliger, G., Weinert, N., \& Zettl, M. (2007). Module Configurator for the Development of Products for Ease of Remanufacturing. In Advances in Life Cycle Engineering for Sustainable Manufacturing Businesses (pp. 47-52). Springer London.

Sladić B., Menadžment kvaliteta isporučilaca, Studio MS, Beograd, 2008

Ward, P. T., Bickford, D. J., \& Leong, G. K. (1996). Configurations of manufacturing strategy, business strategy, environment and structure. Journal of management, 22(4), 597-626.

Westkämper, E., Feldmann, K., Reinhart, G., \& Seliger, G. (1999). Integrated development of assembly and disassembly. CIRP Annals-Manufacturing Technology, 48(2), 557-565.

Zhang, Y., \& Gershenson, J. K. (2002). Questioning the direct relationship between product modularity and retirement cost. The Journal of Sustainable Product Design, 2(1-2), 53-68.

Zhou, Y., WANG, J., BAI, J., \& WU, W. (2014). A Life-Cycle Based Approach to the Remanufacturing Printing Supplies in Shanghai. Advanced Materials Research, 878, 57-65.

\section{ACKNOWLEDGEMENT}

This work was supported by the Serbian Ministry of Education and Science under Grant TR 35017 and TR 32008. 